\title{
PHONOLOGICAL DESCRIPTION OF TEOCHEW DIALECT IN PONTIANAK WEST KALIMANTAN
}

\author{
Lily Thamrin* \\ Fakultas Keguruan dan Ilmu Pendidikan, Universitas Tanjungpura \\ Jl. Jendral Ahmad Yani, Pontianak, Kalimantan Barat 78124, Indonesia \\ lily.thamrin@fkip.untan.ac.id
}

Received: $29^{\text {th }}$ July 2020/Revised: $24^{\text {th }}$ August 2020/Accepted: $20^{\text {th }}$ October 2020

How to Cite: Thamrin, L. (2020). Phonological description of Teochew dialect in Pontianak West Kalimantan. Lingua Cultura, 14(2), 195-201. https://doi.org/10.21512/lc.v14i2.6600

\begin{abstract}
The research aimed to describe the phonological system of the Pontianak Teochew dialect spoken by the Chinese community in West Kalimantan, including vocals, consonants, and tones, using descriptive method. The phonological description in question included both phonetic and phonemic descriptions with the subject of language that objectively and accurately describes the current aspects of Teochew's phonology. The phonetic system of the Pontianak Teochew language would be articulately identified based on the way sounds are formed by human speech tools, namely through consonants, vocals and diphthong. The research data were obtained from three Pontianak Teochew informants who used the Teochew dialect as their daily conversation language. The informants were around 70-75 years old. Based on the research results, there are 18 consonant phonemes, 88 vocal phonemes, and eight tones. The research results show that the Pontianak Teochew dialect has its own characteristics that distinguish it from the other regional Teochew dialects.
\end{abstract}

Keywords: phonological system, phonetics system, Teochew dialect

\section{INTRODUCTION}

On a daily basis, language is utterly needed to communicate among people. Language is a tool to convey ideas, thoughts, and desires to others, and it plays a role in the development of various aspects of human life. Thus, language has a function as a medium to deliver information. The function of language can be studied in two ways, both internally and externally. Internal studies are studies that are only conducted on the internal structure of language, which includes phonological, morphological, syntactic, and semantic structures. This study is conducted in accordance with the procedures and provisions that already exist in linguistic disciplines. Meanwhile, external studies are studies conducted on structures outside the language, such as sociolinguistics, psycholinguistics, neurolinguistics, and so on (Gani \& Arsyad, 2019).

According to Chelaeh et al. (2017), phonological aspects require a system of phoneme inventory and involve phonological processes. Phonology is a part of language science that studies sound. The first object of phonological study is sound (fon), which is called (phonetics), and the second one explains phonemes, which is called phoneme system (phonemic) (Gani \& Arsyad, 2019). It includes the sounds of language, those related to sound formation, sounds as air vibrations, and audible sounds (all are studied by phonetics) as well as those related to the function of sound in communication (Nafisah, 2017).

Pontianak has three largest ethnic groups, namely the Malays, the Dayaks, and the Chinese. The languages used by the Chinese are Teochew and Hakka, which are still preserved by the Pontianak Chinese. However, the Teochew or Khek language used in Pontianak is no longer the original language. However, it is a special language generally used by the Chinese people in Indonesia that has been assimilated into the local language. Language development can be influenced by speakers who use the language itself. Every language speaker has a different background. Another factor that influences the development of a language is the geographical location of an area (Afidah \& Mardikantoro, 2019). Meanwhile, the phonological system is a language system used by the community to differentiate itself from other communities (Sari \& 
Syaputri, 2019). In this case, the regional language of each ethnic group affects phonological pronunciation (Taembo, 2016).

Pontianak's geographical location is precisely crossed by the equator. It is one of the tropical regions with quite high temperatures and high humidity. Astronomically, Pontianak is located between $0^{\circ} 02^{\prime}$ $24^{\prime \prime}$ North Latitude and $0^{\circ} 05^{\prime} 37^{\prime \prime}$ South Latitude, and between $109^{\circ} 16^{\prime} 25^{\prime \prime}$ East Longitude and 109 23' 01" East Longitude. Overall, Pontianak is bordered by the areas of Mempawah regency and Kuburaya regency (Pemerintah Kota Pontianak, 2019).

Pontianak Teochew dialect is a dialect that has been assimilated into the local language, so it is slightly different from the original Teochew dialect from Guangdong China. This is because it is influenced by the process of language assimilation from the Malay dialect of Pontianak and Bahasa Indonesia. Assimilation is a process of mutual influence between one sound with another that results in phonemes or sounds that are almost the same. They affect each other as a result of an almost identical environment (Nafisah, 2017).

During the development, social dialects in dialectology studies refer to dialects spoken by speakers of certain regions based on the speakers' social variables (Widyastuti, 2019). These changes can occur at the level of phonology, morphology, semantics, and lexical (Suharyanto, 2015). In this case, neighboring isolates play a role in the process of the occurrence of a dialect. Therefore, the research areas have special characteristics and potentially contribute to the characterization of the study area isolates, namely variations in language units, morpheme, sentences, and lexicon (Reniwati et al., 2016).

The Teochew dialect is a Hokkien sub dialect, which is translated in the Min Nan language (Li \& Huang, 2017). Tiosua dialect is also called a Teochew dialect, spread in Eastern Guangdong province, the coastal Chaoshan area (Chaozhou city, Jieyang city, Shantou city, Fengshun county), and the areas where Chinese overseas are the oldest, so it becomes the most special dialect in the country. Teochew dialect belongs to the Min Nan language, which is one of the eight major languages of Chinese dialects with unique phonology, rich vocabulary, special grammatical structures, many ancient meanings, humorous, full of expressiveness, and other characteristics (陈泽如, 2016).

Speakers of the Teochew dialect in China and Indonesia are different in terms of phonology, morphology, and the choice of language use in daily life. Different elements of language and culture influence the differences. The Pontianak Teochew dialect is more influenced by Indonesian, Pontianak Malay, and Pontianak Khek. Indonesian researchers rarely carry out research on the language or dialect spoken by the Chinese. Therefore, the researcher conducts research about the phonology of the Pontianak Teochew dialect. The researcher is also a speaker of the Pontianak Teochew dialect and masters both spoken and written
Mandarin.

\section{METHODS}

A descriptive method is used in the research. It aims to obtain a complete and valid description of the phonology of the Pontianak Teochew dialect. The phonological description includes phonetic and phonemic descriptions with language points which objectively and accurately describe the current phonological aspects of the Pontianak Teochew dialect. Data collected using a descriptive method are in the form of words and images, not numbers, which contain data excerpts to provide an overview of the report's presentation. Thus, the researcher analyzes the rich data, which are as far as possible in its original form.

Validly in a language is determined by the data source of the concerned language. In the study of phonology, the priority is to use primary data so that secondary data should be avoided (Erniati, 2020). Data are collected through interviews and conversations with informants who use Pontianak Teochew dialect. The researcher uses 《fang yan diaocha zi biao方言 调查字表》(She hui ke xue yuan yan jiu suo社会 科学院研究所, 2004), 《Dialect Survey Glossary》. Dialect Survey Glossary is first used by Zhao Yuanren to conduct a field survey in order to complete his research report. After conducting the survey, the survey materials are sorted and made into survey reports or scientific research papers written into standard operating procedures. For the Chinese dialect survey in the research of dialect phonetics, the vocabulary is 3.810 words commonly used in everyday life. The chosen words are arranged according to the initials, final, and Guangyun tone. The Dialect Survey Glossary is used to investigate the dialect of a language so that it can draw important points in the phonetic evolution of dialects in ancient and modern times (李蓝 Li lan, 2018).

During the analysis, the obtained data are analyzed on the basis of phonetic transcription analysis. In other words, the recording of sound in the form of written symbols or phonetic symbols that have been determined by The International Phonetic Associations (IPA) is used so that it can be easily understood by readers and does not cause misinterpretation. In order to map the consonant sounds, vowels, and tones, the recordings in the form of Pontianak Teochew dialect sound system are observed. The research emphasizes on the field of proving the status of phonemes and their realization, the structure of phonemes in the Pontianak Teochew dialect. This subject will be devoted to several aspects, including phonetics and phonemic Teochew dialect. Informants are native speakers of the Teochew language.

The informants are three people with age ranging from 70 to 75 years. Informants are selected based on their level of mastery of Teochew language and whether they can read simple Han characters 
spoken in Teochew. The three informants are fluent in Teochew language and have a background in mandarin education at the junior high school level. The informants are descendants of the second generation. The mobility of the informants outside their place is very limited. Informants can speak Indonesian, Khek, and a little bit Mandarin.

\section{RESULTS AND DISCUSSIONS}

Chen (2008) has been researching the Teochew dialect in Laos, Vientiane, specifically the phonology and phonetics of the language. Based on the results of this research, it is known that the Laos Teochew Vientiane dialect consonants have 19 consonants, 77 vocals, and 8 tones. According to the data received from informants, phonological variations found in Pontianak Teochew dialect include variations of consonant sounds, vowels, and tones. The phonology found in the Pontianak Teochew dialect has 18 consonant phonemes, 88 vowels, and 8 notes.

Based on data obtained by consonant sounds in Pontianak Teochew dialect in West Kalimantan, 18 consonant sounds are found, they are $[\mathrm{p}],\left[\mathrm{p}^{\mathrm{h}}\right],[\mathrm{b}]$, $[\mathrm{m}],[\mathrm{t}],\left[\mathrm{t}^{\mathrm{h}}\right],[\mathrm{n}],[1],[\mathrm{z}],[\mathrm{ts}],\left[\mathrm{ts}^{\mathrm{h}}\right],[\mathrm{s}],[\mathrm{k}],\left[\mathrm{k}^{\mathrm{h}}\right][\mathrm{g}]$, $[\mathrm{p}],[\mathrm{h}],[\varnothing]$.

The consonant sound [p] is found in the vocabulary 补 [pou], 比 [pi], 排 [pai], 飞 [pue], 盘 [pua], 斧 [pou], 布 [pou], 方 [pay].

The consonant sound $\left[\mathrm{p}^{\mathrm{h}}\right]$ is found in the vocabulary 香 [ $\left.\left.\mathrm{p}^{\mathrm{h}} \mathrm{a}\right)\right]$, 跑 [ $\left.\mathrm{p}^{\mathrm{h}} \mathrm{au}\right]$, 蜂 [ $\left.\mathrm{p}^{\mathrm{h}} \mathrm{a}\right]$, 骗 [ $\mathrm{p}^{\mathrm{h}}$ ien].

The consonant sound [b] is found in the vocabulary 梅 [bue], 卖 [boi], 米 [bi], 马 [be], 无 [bo].

The consonant sound $[\mathrm{m}]$ is found in the vocabulary 门 [men], 毛 [mo], 名 [mia], 晚 [me].

The consonant sound $[\mathrm{t}]$ is found in the vocabulary 刀 [to], 袋 [to], 灯 [tey], [tiau], 中 [ton].

The consonant sound $\left[\mathrm{t}^{\mathrm{h}}\right]$ is found in the vocabulary 看 [ $\left.\mathrm{t}^{\mathrm{h}} \mathrm{oi}\right]$, 太 [ $\left.\mathrm{t}^{\mathrm{h}} \mathrm{ai}\right]$, 谈 [ $\left.\mathrm{t}^{\mathrm{h}} \mathrm{am}\right]$.

The consonant sound [n] is found in the vocabulary 年 [ni], 努 [nou], 两 [no], 软 [nen].

The consonant sound [1] is found in the vocabulary 罗 [lo], 路 [lou], 漏 [lau], 里 [lai].

The consonant sound $[\mathrm{z}]$ is found in the vocabulary 入 [zip], 热 [zuak], 二 [zi], 日 [zit].

The consonant sounds [ts] is found in the vocabulary 走 [tsau], 知 [tsai], 钟 [tsen], 注 [tsu], 水 [tsui].

The consonant sounds $\left[\mathrm{ts}^{\mathrm{h}}\right]$ is found in the vocabulary 唱 [tshio], 青 [tshe], 秋 [ts $\left.{ }^{\mathrm{h}} \mathrm{iu}\right]$, 抄 [ $\left.\mathrm{ts}^{\mathrm{h}} \mathrm{au}\right]$, 手 [ $\left.\mathrm{ts}^{\mathrm{h}} \mathrm{iu}\right]$, 抢 [ $\mathrm{ts}^{\mathrm{h}}{ }^{\mathrm{i}} \mathrm{io}$.

The sound of the consonant $[\mathrm{s}]$ is found in the vocabulary 三 [sa], 生 [se], 色 [sek], 疏 [su], 社 [sia].

The consonant sound $[\mathrm{k}]$ is found in the vocabulary 歌 [kua], 桥 [kio], 狗 [you], 旗 [ki].

The consonant sounds $\left[\mathrm{k}^{\mathrm{h}}\right]$ is found in the vocabulary 去 $\left[\mathrm{k}^{\mathrm{h}} \mathrm{e}\right]$, 哭 $\left[\mathrm{k}^{\mathrm{h}} \mathrm{au}\right]$, 可 $\left[\mathrm{k}^{\mathrm{h}} \mathrm{O}\right]$, 期 $\left[\mathrm{k}^{\mathrm{h}} \mathrm{i}\right]$, 吸 [k $\left.\mathrm{k}^{\mathrm{hip}}\right]$, 苦 $\left[\mathrm{k}^{\mathrm{h}} \mathrm{Ou}\right]$.

The consonant sound $[\mathrm{g}]$ is found in the vocabulary 玉 [gek], 吴 [gou], 牙 [ge], 牛 [gu], 月 [gue?].

The consonant sound [n] is found in the vocabulary 硬 [ye], 俄 [yo], 五 [you].

The consonant sound [h] is found in the vocabulary 何 [ho], 府 [hu], 墟 [hu], 福 [hok].

The consonant zero sound $[\varnothing]$ is found in the vocabulary 我 [ua], 爷 [ia], 英 [ii]], 幼 [iu].

Based on the data, the consonant correspondence in Teochew language spoken by three informants is the same, namely Ancient turbid initials that sounded unvoiced, vowel plosive, and affricate. Most consonants are read as aspirated sound. Only a few are read as aspirated sound.

Based on data obtained by the vocal sounds found in the Pontianak Teochew dialect in West Kalimantan, there are 88 vocal sounds. They are: [i], [u], [a], [ia], [ua], [e], [ue], [o], [io], [u], [ai], [uai],

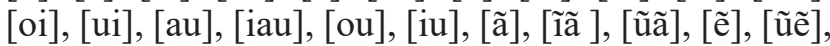

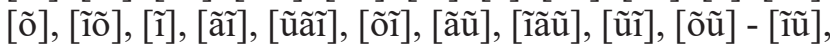
[am], [iam], [uam], [om], [im], [an], [ien], [uen], [un], [in], [un] ], [uan], [ay], [iay], [uay], [en], [uen], [on], [iop], [uy], [uy], [ap], [iap], [steam], [op], [ip], [at], [strong], [it], [ut], [oit], [ak], [iak], [uak], [ek], [uek] ], [ok], [iok], [uk], [ik], [a?], [ia?], [ua?], [ue?], [o?], [io?], [i?], [u?], [e?], [ẽ?], [ũẽ?], [õ?], [m], ['่].

The vowel sound [i] is found in the vocabulary 地 [ti], li [li], 池 [ti], 齿 [k $\left.\mathrm{k}^{\mathrm{hi}}\right]$.

The vowel sound $[\mathrm{u}]$ is found in the vocabulary 入 $[\mathrm{zu}]$, 有 $[\mathrm{u}]$, 区 $\left[\mathrm{k}^{\mathrm{h}} \mathrm{u}\right]$.

The vowel sound [a] is found in the vocabulary 巴 [pa], 早 [tsa].

The vowel sound [it] is found in the vocabulary 车 [ $\mathrm{ts}^{\mathrm{h}} \mathrm{ia}$, 写 [sia], 谢 [tsia].

The vowel sound [ua] is found in the vocabulary 华 [hua], 拖 [ $\left.\mathrm{th}^{\mathrm{h}} \mathrm{ua}\right]$, 娶 [ $\left.\mathrm{ts}^{\mathrm{h}} \mathrm{ua}\right]$.

The vowel sound [e] is found in the vocabulary 爬 [pe], 加 [ke], 些 [se], 债 [tse].

The vowel sound [ue] is found in the vocabulary 杯 [pue], 花 [hue], [cake].

The vowel sound $[\mathrm{o}]$ is found in the vocabulary 保 [po], 多 [to], 哥 [ko], 初 [ $\mathrm{ts}^{\mathrm{h}} \mathrm{o}$ ].

The vowel sound [Io] is found in the vocabulary 票 [phio], 姜 [kio].

The vowel sounds $[\mathrm{w}]$ is found in the vocabulary 吕 [lu], 去 [ $\left.\mathrm{k}^{\mathrm{h}} \mathrm{u}\right]$, 鱼 [hu], 猪 [tu].

The vowel sounds [ai] is found in the vocabulary 排 [pai], 来 [lai], 介 [kai].

The vowel sound [uai] is found in the vocabulary 怪 [kuai], 淮 [huai].

The vowel sound [oi] is found in the vocabulary 批 [ $\left.\mathrm{p}^{\mathrm{h}} \mathrm{oi}\right]$, 题 [toi], 街 [koi], 矮 [oi].

The vowel sounds [ui] is found in the vocabulary 悲 [pui], 辉 [hui], 对 [tui], 开 [ $\left.\mathrm{k}^{\mathrm{h}} \mathrm{ui}\right]$.

The vowel sound [au] is found in the vocabulary 老 [lau], 交 [you], 欧 [au].

The vowel sound [Iau] is found in the vocabulary 焦 [tsiau], 绍 [siau].

The vowel sound [ou] is found in the vocabulary 
布 [pou], 古 [kou], 都 [tou], 后 [hou].

The vowel sound [Iu] is found in the vocabulary 丢 [tiu], 友 [iu], 手 [ts ${ }^{\mathrm{h} i u}$, 初 [ $\left.\mathrm{ts}^{\mathrm{h}} \mathrm{iu}\right]$

The vowel sound [ã] is found in the vocabulary 担 [tã], 三 [sã], 酵 [kã], 妈 [mã].

The vowel sound [iã] is found in the vocabulary 兵 [pĩã], 京 [kĩã], 正 [tsĩã], 雅 [yĩa]].

The vowel sound [ $\tilde{u} \tilde{a}]$ is found in the vocabulary of 半 [pũã].

The vowel sound [ẽ] is found in the vocabulary 病 [pẽ], 猛 [mẽ], 星 [tsh $\left.{ }^{\mathrm{e}}\right]$.

The vowel sound [ũ̃e] is found in the vocabulary 横 [hũẽ], 关 [kũẽ], 妹 [mũẽ].

The vowel sound [õ] is found in the vocabulary 俄 [ทõ], [mõ], 两 [nõ].

The vowel sound [ĩo] is found in the vocabulary 娘 [nĩõ], 羊 [ĩ̃]].

The vowel sound [ĩ] is found in the vocabulary

钱 [tsĩ], 扇 [sĩ], 迷 [mĩ].

The vowel sound [ã̃] is found in the vocabulary 卖 [mãĩ], 爱 [ãĩ], 还 [hãĩ].

The vowel sound [ũãi] is found in the vocabulary of 果 [kũãĩ].

The vowel sound [õ̃̃] is found in vocabulary 殿

[tõĩ $]$, 闲 [õ̃̃ ], 虫 [tsh $\left.{ }^{\mathrm{o}} \tilde{1}\right]$, 第 [tõĩ $]$.

The vowel sound [ $\tilde{u} 1]$ is found in the vocabulary 县 [hũĩ], 危 [yũ̃̃].

The vowel sound [ãũ] is found in the vocabulary 好 [hãũ], 傲 [ãũ].

The vowel sound [ĩãu] is found in the vocabulary of 苗 [mĩãũ].

The vowel sound [õu] is found in the vocabulary 虎 [hõũ], 奴 [nõũ].

The vowel sound [ $\tilde{1} \tilde{u}]$ is found in the vocabulary

休 [hĩũ], 扭 [nĩũ].

The vowel sound [am] is found in the vocabulary 含 [kam], 甘 [kam], 针 [tsam].

The vowel sound [iam] is found in the vocabulary 点 [tiam], 咸 [kiam], 占 [tsiam].

The vowel sound [iam] is found in the vocabulary 点 [tiam], 咸 [kiam], 占 [tsiam].

The vowel sound [om] is found in the vocabulary

口用头部 冲撞 [kom].

The vowel sound [im] is found in the vocabulary

林 [lim], 深 [sim], 寻 [tsim], 淹 [im].

The vowel sound [an] is found in the vocabulary 班 [pan], 牵 [ $\left.\mathrm{k}^{\mathrm{h}} \mathrm{an}\right]$.

The vowel sound [an] is found in the vocabulary 班 [pan], 牵 [ $\left.\mathrm{k}^{\mathrm{h}} \mathrm{an}\right]$.

The vowel sound [ien] is found in the vocabulary

珍 [tien], 煎 [tsien], 电 [tien].

The vowel sound [ien] is found in the vocabulary

珍 [tien], 煎 [tsien], 电 [tien].

The vowel sound [uan] is found in the vocabulary 愿 [yuan], 万 [buan], 銮 [luan].

The vowel sound [un] is found in the vocabulary 银 [yun], 近 [kun].

The vowel sound [in] is found in the vocabulary

面 [min], 蝇 [sin], 藤 [tin].

The vowel sound [un] is found in the vocabulary 春 [tsun], 滚 [kun]. 寸 [tsun], [kun], 文 [bun].
The vowel sound [an] is found in the vocabulary

红 [an], 唐 [than], 东 [tan].

The vowel sound [Ian] is found in the vocabulary

凉 [liay], 天 [thiay], 香 [hiay], 娟 [kiay].

The vowel sound [uan] is found in the vocabulary 装 [tsuan], 光 [kuan].

The vowel sound [en] is found in the vocabulary

宫 [ken], 民 [men], 仁 [zen], 轻 [khen], 兴 [hen]. The vowel sound [ue] is found in the vocabulary 荣 [uen], 永 [uen].

The vowel sound [oy] is found in the vocabulary

of 中 [ton], 充 [tshoy], 封 [hoy], 公 [koy].

The vowel sound [un] is found in the vocabulary

郎 [luy], 仓 [khuy], 段 [tur].

The vowel sound [ap] is found in the vocabulary

答 [tap], 杂 [tsap], 鸽 [hap].

The vowel sound [iap] is found in the vocabulary

夹 [kiap], 蝶 [tiap], 接 [tsiap], 涉 [siap].

The vowel sound [uap] is found in the vocabulary

法 [huap].

The vowel sound [op] is found in the 口的插入

[tsop] vocabulary.

The vowel sound [ip] is found in the vocabulary

立 [lip], 给 [kip], 执 [khip].

The vowel sound [at] is found in the vocabulary

力 [lat], 贼 [tshat].

The vowel sound [uat] is found in the vocabulary

发 [huat], 伐 [huat].

The vowel sound [it] is found in the vocabulary

橘 [kit], 蜜 [bit].

The vowel sound [oit] is found in the vocabulary

节 [tsoit], 八 [poit].

The vowel sound [ak] is found in the vocabulary

pak [pak], 角 [ak], bak [bak], 乐 [lak].

The vowel sound [iak] is found in the vocabulary

略 [liak], 雀 [khiak], 弱 [niak], 跃 [iak].

The vowel sound [uak] is found in the vocabulary

$\mathrm{ku}$ [kuak], 越 [uak].

The vowel sound [ek] is found in the vocabulary

碧 [pek], 式 [sek], 特 [thek], 陆 [lek].

The vowel sound [uek] is found in the vocabulary

$\mathrm{h}$ [huek].

The vowel sound [ok] is found in the vocabulary

牧 [mok], 足 [tsok], 国 [kok]

The vowel sound [iok] is found in the vocabulary

曲 [khiok], 蓄 [hiok], 国 [kok].

The vowel sound [uk] is found in the vocabulary of 不 [puk], 屈 [khuk].

The vowel sound [uk] is found in the vocabulary

乞 $[\mathrm{khck}]$.

The vowel sound [aokal] is found in the vocabulary 甲 [ka?], 搭 [ta?], 插 [tsha?].

The vowel sound [Ia?] is found in the vocabulary 壁 [pia?], 摘 [tia?], 食 [tsia?], 额 [hia?].

The vowel sound [ua,] is found in the vocabulary 泼 [phua?], 割 [kua?], 活 [ua?].

The vowel sound [e?] is found in the vocabulary

百 [pe?], 历 [le?], 册 [tshe?].

The vowel sound [ue,] is found in the vocabulary

月 [gue?], 刷 [sue?].

The vowel sound [o?] is found in the vocabulary 
薄 [po?], 桌 [to?], 托 [tho?].

The vowel sound [io?] is found in the vocabulary 惜 [sio?], 石 [tsio?], 页 [hio?].

The vowel sound [i?] is found in the vocabulary 铁 [thi?], 接 [tsi?], 舌 [tsi?].

窟 [khu?]

The vowel sound [u?] is found in the vocabulary 脉 [mẽ?].

The vowel sound [ẽ?] is found in the vocabulary 物 [mũẽ?]

Vocabulary sounds [ũẽ?] is found in vocabulary

The consonant sound [0̃?] is found in the vocabulary 膜 [mõ?].

The consonant sound $[\mathrm{m}]$, found in the vocabulary 姆 [m].

The consonant sound [í] is found in the vocabulary 远 [hì], 黄 [ì].

In Pontianak's Teochew dialect, there is one vocabulary that is pronounced differently from the other. For instance, vocabulary groups included in the group "Gu Shanshe 古山摄” vowel suffixes are spelled [ì], another vowel. In addition, if the vowel [u] , the vowel ending [-n], [-k], the vowel pronounced by the informant will change to [r]. Suffixes in one category and one group are pronounced [un]. The Pontianak Teochew vocal has its own characteristics. It uses nasal terminal consisting of a front nasal and a back nasal, namely [-m], [- n], [- $\mathrm{p}]$. In addition, the Entering Tone Words consists of four types of plosive terminals, namely [-p], [- t], [- k], and [?]. It also has many nasal rhymes such as 钱 [tsĩ], 虎 [hõũ] and others.

Based on data obtained from the field, the Pontianak Teochew dialect is grouped into eight tones of voice that are further divided into "yin and yang".

The monosyllabic tone is divided into tone levels, rising tones, falling tones, and entering tones. Each is consisting of devoiced and voiced, a total of eight tones. Chongqi and Ruiying, 2018) have written a comparative research on phonetic systems of five documents about Teochew-Swatow dialect during the period of Qing Dynasty and The Early Republic of China. The analysis of the tones of the late Qing
Dynasty and the early Republic of China shows that there are eight tones in five Chinese and Western Teochew dictionaries. The tones of the Western Teochew dialect are even higher. For instance, Fideer's Swatow Dialect Phonetic and Meaningful Characters Dictionary uses western music staves to describe the tonal value specifically.

The phonology of every language in the world has its own characteristics, especially in the use of vocals and consonants (Sutarsih, 2017). Meanwhile, (吴芳 Wufang, 2018) states that the phonological system of the Teochew dialect used in Paris is slightly different from the original Teochew language used in mainland China. The Teochew Chinese in Paris migrated from Southeast Asia in the late 1970s. They generally live in Districts 13 and 18. Many secondgeneration Teochew people who were born and raised in Paris can speak Teochew, but the language has changed. The language most fluently spoken is French, and there are Teochew speakers in Paris who can also speak Cantonese, Mandarin, and English. Due to its history of immigration and its special linguistic environment, the Paris Teochew dialect presents a complex type of linguistic contact. The dialect has clear traces of Southeast Asian languages, and at the same time combines components of French and English. Apart from that, there is also a mixture of other dialects, which is a distinctive feature of the Paris Teochew dialect.

Based on the research results, it is found that the phonology of the Pontianak Teochew dialect has changed. In other words, it is different from the phonology of the original Teochew dialect in mainland China, particularly in Jieyang city. This language change occurred because the Pontianak Teochew Chinese had lived in Pontianak for hundreds of years from the time when their ancestors started to immigrate to West Kalimantan. Also, there had been language assimilation and cultural acculturation in the Chinese tribe, which resulted in the Teochew dialect having its own phonetic characteristics.

Every speaker has a phonological awareness of the sounds in his/her language. Meanwhile, each language has a different phonological system

Table 1 Teochew Dialect Pontianak Tones

\begin{tabular}{clcll}
\hline Tone Number & \multicolumn{1}{c}{ Tones Name } & Pitch Contour & \multicolumn{1}{c}{ Description } & \multicolumn{1}{c}{ Example } \\
\hline 1 & Yin Level (阴平) & 33 & Mid & 珠 [tsu], 知 [tsai] \\
2 & Yang Level (阳平) & 55 & High & 铜 [tan], 陈 [tan], \\
3 & Yin rising (阴上) & 53 & Falling & 感 [kam], 早 [tsa] \\
4 & Yang Rising (阳上) & 35 & High Rising & 老 [lau], 坐 [tso] \\
5 & Yin Departing (阴去) & 213 & Low Rising & 吊 [tiau], 教 [ka] \\
6 & Yang Derpating (阳去) & 11 & Low & 地 [ti], 谢 [sia] \\
7 & Yin Entering (阴入) & 21 & Low Checked & 竹笔 [pit], 急 [kip] \\
8 & Yang Entering (阳入) & 4 & High Checked & 杂 [tsap], 合 [ap] \\
\hline
\end{tabular}


(Suherman, 2012). It applies to Pontianak Teochew language and Jieyang Teochew language. This is due to the existence of several phonetic features of the Pontianak Teochew language that are not found in the phonetic features of the Jieyang Teochew language. Therefore, there is a change in the pronunciation of several vocals (initial) of the Pontianak Teochew dialect. Voicing or changing of one of the vocals into another vocal is influenced by the sound close to the consonant, or in the form of depalatalization, which is the change from one consonant to another because the adjacency of the place out letters.

\section{CONCLUSIONS}

Based on the analysis, it can be concluded that the Pontianak Teochew community still uses the Teochew dialect although it has been hundreds years since the immigration of their ancestors from Guangdong, China. Based on the obtained data, Pontianak Teochew dialect in West Kalimantan has 18 consonant sounds, and eight variations in the pitch of the tones, which are divided into "yin and yang".

Based on the data, the consonant correspondence in Teochew language, namely Ancient turbid initials sounded as unvoiced sound, vowel plosive, and affricate. Most consonants are read as aspirated sound. Only a few are read as aspirated sound. The Pontianak Teochew vocal has its own characteristics. It has a nasal terminal consisting of a front nasal and a back nasal, namely [-m], [- n], and [- y]. In addition, the Entering Tone Words consists of four types of plosive terminals, namely [-p], [- t], [- k], amd [?]. It also has many nasal rhymes such as 钱 [tsĩ], 虎 [hõũ] and others. The monosyllabic tones are divided into tone levels, rising tones, falling tones, and entering tones, that each consisting of devoiced and voiced, a total of eight tones.

The research in the Teochew dialect in West Kalimantan can be further developed if the research is still around the dialectological studies. Research on the Teochew dialect in West Kalimantan province, Pontianak can also be studied using sociodialectological studies and at other levels, such as at the level of morphology, syntax, or semantics.

\section{REFERENCES}

Afidah, A. U., \& Mardikantoro, H. B. (2019). Variasi Fonologi dan Leksikon Bahasa Jawa di Kabupaten Cilacap (Kajian) Geografi Dialek di Perbatasan Jawa-Sunda. Jurnal Sastra Indonesia, 8(2), 78-87. https://doi.org/10.15294/jsi.v8i2.33713.

Chelaeh, M., Aman, R., Hamid, S. A., Othaman, N. N., Ruslan, S., Bakar, N. A., Salam, R. A., Fadzil, F. H. M., Sinur, M. D. (2017). Penerokaan maklumat linguistik dalam dialek Melayu Jugra: Penelitian fonologi struktural. E-Bangi: Journal of Social Sciences and Humanities, 12(3), 1-29.
Chen, X. (2008). 老挝万象市的潮州话. 湛江师范学院学 报, 29(2), 62-65.

Chongqi, M., \& Ruiying, M. (2018). 清末民初潮汕五种 中西闽南方言辞书音系比较研究 (A Comparative Recearch on Phonetic Systems of Five Documents about Teochew-Swatow Dialect During the Period of Qing Dynasty and The Early Republic of China). 汉 藏语学报语学报, 10, 127-148.

Erniati, N. (2020). Sistem fonologi bahasa Melayu dialek Ambon. BEBASAN Jurnal Ilmiah Kebahasaan Dan Kesastraan, 6(2), 113-124. https://doi.org/10.26499/ bebasan.v6i2.116.

Gani, S., \& Arsyad, B. (2019). Kajian Teoritis Struktur Internal Bahasa (Fonologi, Morfologi, Sintaksis, dan Semantik). A Jamiy: Jurnal Bahasa Dan Sastra Arab, 7(1), 1-20. https://doi.org/10.31314/ ajamiy.7.1.1-20.2018.

Li, Y., \& Huang, X. (2017). Generality of Chaoshan township culture. Overseas Chinese Journal of Bagui, 1, 56-66.

Nafisah, S. (2017). Proses fonologis dan pengkaidahannya dalam kajian fonologi generatif. Deiksis, 9(01), 7078. https://doi.org/10.30998/deiksis.v9i01.940.

Pemerintah Kota Pontianak. (2019). Kondisi geografis kota Pontianak. Retrieved from https://www. pontianakkota.go.id/tentang/geografis.

Reniwati, R., Noviatri, N., Aslinda, A., \& Midawati, M. (2016). Bahasa Minangkabau di daerah asal dengan bahasa Minangkabau di daerah rantau Malaysia: Kajian dialektologis. Jurnal Arbitrer, 3(2), 173-180. https://doi.org/10.25077/ar.3.2.173-180.2016.

Sari, D. P., \& Syaputri, K. D. (2019). A study of phonological system of Mentok dialect of Bangka language in Pusuk district of Kelapa West Bangka region. Jurnal Ilmiah Bina Bahasa, 12(1), 33-43. https://doi. org/10.33557/binabahasa.v12i1.458

She hui ke xue yuan yan jiu suo 社会科学院研究所. (2004). Fang yan diao cha zi biao 方言调查字表. The Commercial Presss 商务印书馆出版社.

Suharyanto. (2015). Perubahan fonem dalam dialek Melayu Ambon. Widyaparwa, 43(1), 15-25. https://doi. org/10.26499/wdprw.v43i1.102.

Suherman, A. (2012). Perubahan fonologis kata-kata serapan bahasa Sunda dari bahasa Arab: Studi kasus pada masyarakat Sunda di Jawa Barat, Indonesia. Sosiohumanika, 5(1), 21-38. https://doi.org/10.2121/ sosiohumanika.v5i1.456.

Sutarsih, S. (2017). Penanda fonologi bahasa Jawa dalam tuturan masyarakat Tionghoa di Gang Baru Semarang. Aksara, 29(1), 89-102. https://doi. org/10.29255/aksara.v29i1.103.89-102.

Taembo, M. (2016). Kajian dialek Sosial fonologi Bahasa Indonesia. Kandai, 12(1), 1-16.

Widyastuti, T. (2019). Bahasa Sunda dialek Pangandaran di kecamatan Sidamulih (Kajian Fonologis). Lokabasa: Jurnal Kajian Bahasa, Sastra, dan Budaya Daerah serta Pengajarannya, 8(1), 101-111. https://doi. org/10.17509/jlb.v8i1.15971.

吴芳 Wufang. (2018). 巴黎潮州华人与潮州话概说. 贺州 学院学报, 4(8).

李蓝 Li lan. (2018). 汉语方言调查技术取得历史性突破 
Hanyu fangyan diaocha jishu qude lishi xing tupo. 中国社会科学报 Zhongguo Shehui Kexue Xuebao.

陈泽如. (2016). 潮汕方言研究综述. 现代语文: 下旬.

语言研究, 8,11-13. 